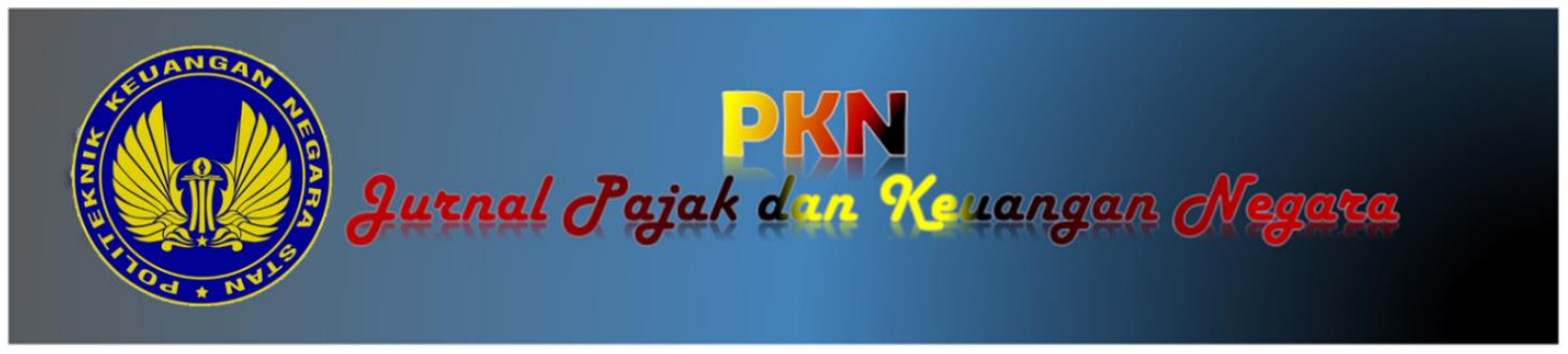

\title{
KESEHATAN KEUANGAN DAN VALUASI BJBR MENGGUNAKAN RISK BASED BANK RATING METHOD
}

\author{
Agung Dinarjito, \\ Politeknik Keuangan Negara STAN \\ Dinar Arisandy \\ Politeknik Keuangan Negara STAN \\ Alamat Korespondensi: agung.dinarjito@pknstan.ac.id
}

INFORMASI ARTIKEL
Diterima Pertama
[30 08 2021]
Dinyatakan Diterima
[13 09 2021]
KATA KUNCl:
[tingkat kesehatan perbankan, profil risiko,
rentabilitas, kecukupan modal, valuasi,
dividend discount model]

KLASIFIKASI JEL:

[C31, G10, G29, N65]

\begin{abstract}
The COVID-19 pandemic has given an impact on the health of banks in Indonesia, one of which is the West Java and Banten Bank (BJBR). This study aims to assess the health of BJBR before and during the covid-19 pandemic and to find the intrinsic value of $B J B R$ shares that can be used as an evaluation of the company's performance. This research is a descriptive quantitative research. BJBR health analysis was carried out using the Risk Based Rating or RGEC and the intrinsic value analysis was carried out using the Dividend Discount Model (DDM). The authors used data from the 2018-2020 of BJBR financial statements. The results showed that in general, the soundness of $B J B R$ was very healthy and the intrinsic value of BJBR's shares was Rp. 1,659.33 or BJBR's share price is currently sold below its intrinsic value. This research is expected to provide information on the impact of the pandemic on banking, especially BJBR so that the Government and the Financial Services Authority can provide support to banks. In addition, this research can be used as a reference by investors who are interested in $B J B R$ shares.
\end{abstract}

\section{ABSTRAK}

Pandemi covid-19 telah memberikan dampak pada kesehatan perbankan di Indonesia, salah satunya Bank Jawa Barat dan Banten (BJBR). Penelitian ini bertujuan untuk untuk menilai kesehatan BJBR sebelum dan selama pandemi covid-19 serta untuk mencari nilai intrinsik saham BJBR yang dapat digunakan sebagai evaluasi kinerja perusahaan. Penelitian ini merupakan penelitian kuantitatif deskriptif. Analisis kesehatan BJBR dilakukan dengan menggunakan Risk Based Rating atau RGEC dan analisis nilai intrinsik dilakukan dengan Dividend Discount Model (DDM). Penulis menggunakan data laporan keuangan BJBR tahun 2018-2020. Hasil penelitian menunjukkan bahwa secara umum, tingkat kesehatan BJBR adalah sangat sehat dan nilai intrinsik saham BJBR adalah Rp1.659,33 atau harga saham BJBR saat ini dijual di bawah nilai intrinsiknya. Penelitian ini diharapkan dapat memberikan informasi dampak pandemic terhadap perbankan, khususnya BJBR agar Pemerintah dan Ototritas Jasa Keuangan dapat memberikan dukungan kepada bank. Selain itu, penelitian ini dapat digunakan sebagai acuan oleh investor yang tertarik saham BJBR. 


\section{PENDAHULUAN}

Selama tahun 2020, kinerja perbankan secara umum di Indonesia mengalami penurunan. Penurunan kinerja ini diakibatkan oleh perlambatan aktivitas di sektor riil dan sector korporasi yang belum beroperasi penuh sebagai akibat dari pandemic covid-19 (Faqir, 2021).

Untuk beberapa kelompok perbankan, kinerjanya ada yang mengalami pertumbuhan. Bank Pembangunan Daerah (BPD) yang rata-rata mengalami pertumbuhan sebesar 5,22\% dan Bank Syariah yang tumbuh sebesar 9,5\%. Pembukaan aktivitas masyarakat di akhir tahun 2020, telah memberikan harapan pulihnya kinerja perbankan. Hal ini dapat dilihat pada Gambar 1.

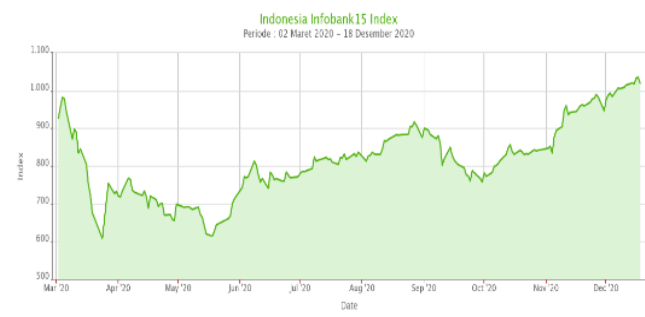

Gambar 1. Indeks Infobank15

Sumber: www.bareksa.com

Namun, kondisi industri perbankan mulai membaik dan dapat bangkit kembali di penghujung tahun 2020. Hal itu salah satunya tercermin pada harga saham industri perbankan pada indeks infobank15. Saham industri perbankan seperti ditampilkan pada Gambar 1 mulai mengalami apresiasi kembali di akhir tahun 2020. Infobank15 merupakan indeks yang mengukur kinerja harga saham 15 bank dengan fundamental yang baik dan likuiditas perdagangannya tinggi (Bursa Efek Indonesia, n.d.).

Sektor perbankan di Indonesia dapat bangkit kembali di tengah pandemi karena kondisi fundamentalnya yang kuat. Kondisi ketahanan perbankan Indonesia pada triwulan II 2020 yang diukur dengan indikator seperti CAR (Capital Adequacy Ratio), ROA (Return on Assets), NIM (Net Interest Margin), BOPO (Beban Operasi terhadap Pendapatan Operasi), NPL (Non Performing Loan), dan LDR (Loan to Deposit Ratio) masih terjaga (Otoritas Jasa Keuangan, 2020).

Kriteria penilaian peringkat rasio-rasio tersebut telah diatur oleh Bank Indonesia sesuai Peraturan Bank Indonesia nomor 13/1/PBI/2011 tentang Penilaian Tingkat Kesehatan Bank Umum dan Surat Edaran Bank Indonesia nomor 13.24/DPNP/2011. Kriteria tersebut pun diatur oleh Otoritas Jasa Keuangan (OJK) melalui
Peraturan OJK nomor 4/POJK.03/2016 tentang Penilaian Tingkat Kesehatan Bank Umum.

Diambil dari Laporan Profil Industri Perbankan Triwulan II 2020, rasio keuangan BUK (Bank Umum Konvensional) di Indonesia, yakni (1) CAR $22.55 \%$ yang masuk peringkat komposit 1, (2) ROA $1,94 \%$ yang masuk peringkat komposit 1 , (3) NIM 4,46\% yang masuk peringkat komposit $1,(4)$ BOPO $84,94 \%$ yang masuk peringkat komposit 1 , (5) NPL 3,10 \% yang masuk peringkat komposit 2, dan (6) LDR 89,1\% yang masuk peringkat komposit 3. Penetapan Peringkat Komposit dikategorikan dalam 5 (lima) Peringkat Komposit. Urutan peringkat yang semakin kecil menunjukkan kondisi bank yang lebih sehat (Bank Indonesia, 2012).

Keseluruhan rasio tersebut merupakan rasio dari BUK yang terdiri dari bank BUMN (Badan Usaha Milik Negara), BUSN (Bank Umum Swasta Nasional) Devisa, BUSN (Bank Umum Swasta Nasional) Non Devisa, BPD (Bank Pembangunan Daerah), dan KCBA (Kantor Cabang Bank Asing) di Indonesia yang berjumlah 110, (Otoritas Jasa Keuangan, 2020b). Dari sekian banyak bank tersebut, 43 di antaranya telah melakukan listing di Bursa Efek Indonesia (BEI) dan tiga di antara yang telah melakukan listing merupakan BPD. BPD tersebut terdiri dari Bank Jawa Timur (kode saham: BJTM), Bank Jawa Barat (kode saham: BJBR), dan Bank Banten (kode saham: BEKS).

BPD Jawa Barat memiliki kinerja yang paling baik di antara ketiga BPD tersebut pada tahun 2020 (Ciptaning, 2020). Berdasarkan laporan keuangan perusahaan periode triwulan III 2020, BPD Jawa Barat memperoleh laba Rp1.2 triliun. Jumlah tersebut meningkat $6,1 \%$ yoy dari periode sebelumnya yang hanya sebesar Rp1.13 triliun. Di sisi lain, BPD Jawa Timur mengalami penurunan laba sebesar 4,3\% yoy dan BPD Banten mengalami kenaikan rugi bersih sebesar $27,09 \%$ yoy pada kuartal yang sama (Bursa Efek Indonesia, 2020).

Padahal, di tahun sebelumnya, BPD Jawa Timur memiliki kinerja yang jauh lebih baik dibandingkan dengan Bank Jawa Barat. Di 2019, laba komprehensif BPD Jawa Timur tumbuh sebesar 9,22\% dari Rp1.26 triliun menjadi Rp1.376 triliun. Di tahun yang sama, BPD Jawa Barat membukukan laba sebesar Rp1.56 triliun. Jumlah tersebut meningkat $0.7 \%$ dari tahun sebelumnya yang sebesar Rp1.55 triliun (Kevin, 2019).

Rohendi (2017), Istihana \& Mulyati (2020) dan Putri (2021) melakukan penelitian atas kesehatan BJBR. Ketiga peneitian tersebut samasama menggunakan rasio keuangan dalam menilai kesehatan, yang membedakan adalah rasio yang digunakan dalam menilai kesehatannya. 
Rohendi (2017) dalam penelitiannya terhadap BJBR tahun 2013-2015 menggunakan metode CAMEL, Istihana \& Mulyati (2020) menilai kesehatan BJBR tahun 2014-2018 hanya dengan menggunakan beberapa rasio keuangan, sedangkan Putri (2021) menilai kesehatan BJBR tahun 2017-2019 menggunakan metode RGEC.

Penelitian-penelitian di atas menghasilkan simpulan yang berbeda. Penelitian Rohendi (2017) menyimpulkan bahwa kesehatan BJBR berada pada peringkat sehat. Sedangkan penelitian Istihana \& Mulyati (2020) menyimpulkan bahwa kinerja BJBR tahun 2014-2017 telah memenuhi batas minimal regulasi yang ada, dan terakhir hasil penelitian Putri (2021) menghasilkan bahwa untuk kesehatan BJBR tahun 2017 pada peringkat sangat sehat, tahun 2018 pada peringkat sehat, dan tahun 2019 pada peringkat sehat.

Berbeda dengan peneliti di atas, Hartono (2020) meneliti kinerja BJBR menggunakan metode kuaitatif dan rasio keuangan. Fokus dari penelitian Hartono (2020) adalah melihat kinerja saham BJBR dan BJTM pada tahun 2016-2018. Hasil dari penelitiannya adalah bahwa BJBR memberikan pengembalian aset dan ekuitas yang lebih baik daripada BJTM.

Kemudian, terkait dengan valuasi saham, Hartono (2020) menggunakan metode kualitatif berupa analisis teknikal MA dan RSI untuk menilai saham BJBR dan BJTM yang hasilnya harga saham BJBR lebih mahal daripada BJTM pada kisaran harga Rp1.800-Rp2.300. Berbeda dengan Hartono (2020), Afandy (2019) melakukan valuasi atas saham BJBR dan BJTM tahun 2017 menggunakan metode DDM. Hasilnya adalah bahwa harga saham intrinsic BJBR adalah Rp2.455,25.

Dari beberapa penelitian di atas terkait kinerja BJBR, terdapat perbedaan tingkat kesehatan BJBR antar waktu. Selain itu, penelitian di atas juga menggunakan metode analisis yang berbeda yang memungkinkan menghasilkan hasil yang bebeda. Di tahun 2017, apabila menggunakan metode CAMEL, kesehatan BJBR berada pada peringkat sehat, namun apabila menggunakan metode RGEC berada pada peringkat sangat sehat. Hal ini salah satunya dikarenakan adanya perbedaan penggunaan rasio keuangan dan metode analisisnya. Kemudian, dari sisi valuasi saham menunjukkan hasil yang berbeda yang salah satu penyebabnya adalah metode analisis dan tahun analisis.

Atas perbedaan hasil di atas, penulis tertarik untuk menilai kembali kesehatan BJBR dan melakukan valuasi saham BJBR. Yang membedakan dengan penelitian sebelumnya adalah bahwa penelitian ini akan menggunakan metode RGEC dengan menggunakan rasio keuangan NPL, LDR, ROA, NIM, dan CAR. Metode ini berbeda dengan metode yang digunakan oleh Putri (2021) yang menggunakan rasio keuangan NPL, LDR, BOPO, ROA dan CAR. Kemudian tahun analisis juga membedakan dengan penelitian sebelumnya, yaitu penulis menggunakan tahun 2018-2020. Perbedaan berikutnya adalah dalam metode valuasi saham dengan pendekatan DDM berupa constant growth method untuk membedakan dengan penelitian Afandy (2019). Perbedaan yang terakhir adalah bahwa penelitian ini ingin melihat tingkat kesehatan BJBR sebelum adanya pandemic covid-19 dan selama pademi covid-19. Tingkat kesehatan BJBR sebelum masa pandemic akan diwakili dengan tahun 2018 dan 2019, sedangkan tingkat kesehatan pada masa pandemic akan diwakili dengan tahun 2020.

Penelitian ini diharapkan dapat memberikan kontribusi pada pengembangan pengetahuan di bidang pengelolaan kinerja perusahaan, terutama di industry perbankan. Selain itu, penelitian ini juga diharapkan dapat memberikan informasi kepada stakeholders, seperti Pemerintah dan Otoritas Jasa Keuangan terkait dampak pandemic covid-19 terhadap kesehatan perbankan. Kemudian, bagi investor atau calon investor, penelitian ini diharapkan dapat menjadi salah satu panduan dalam membuat keputusan investasi.

\section{KERANGKA TEORI}

\subsection{Teori Keagenan}

Tujuan perusahaan dilihat dari sisi pemilik adalah untuk meningkatkan kekayaannya yang biasanya diukur dari harga saham (Titman, Keown, \& Martin, 2018). Untuk memenuhi tujuan tersebut, pemilik akan menunjuk manageme untuk menjalan perusahaan. hubungan seperti ini sering disebut dengan hubungan keagenan.

Untuk menilai kinerja dari agent, biasanya pemilik akan membuat kontrak kinerja. Penilaian kinerja salah satunya dari sisi laporan keuangan yang menggambarkan kinerja keuangan manajemen dalam memenuhi target kontrak yang diamanatkan kepadanya. Kontrak antara agen dengan pemilik kadang akan membuat suatu permasalahan keagenan yang disebut dengan agency conflict.

Jensen \& Meckling (1976) menjelaskan permasalahan keagenan sebagai korelasi antara pemilik perusahaan (principal) dan manajemen (agent) berdasarkan suatu kontrak dalam mengelola perusahaan yang berkaitan dengan penyerahan kewenangan dan kewajiban kepada manajemen pada proses pengambilan keputusan. Alchian \& Demsetz (1972) dikutip dalam Panda \& 
Leepsa, 2017) menyatakan bahwa permasalahan keagenan dapat terjadi karena terdapat perbedaan interest antara pihak prinsipal dan pihak agen. Sebagai agen, agen akan melaksanakan pekerjaan untuk mencapai tujuan dari pemilik. Menurut Lestari (2011) yang dikutip dalam Dinarjito (2018) menyatakan bahwa utang dan penerapan tata kelola yang baik menjadi salah satu cara untuk mengatasi masalah keagenan.

Untuk menilai apakah agent dalam hal ini manajemen apakah telah melakukan tugasnya dengan baik, maka penilaian kinerja menjadi salah satu alatnya. Untuk perbankan, penilaian kinerja sering menggunakan penilaian kesehatan perbankan sesuai dengan regulasi yang ada. Semakin bagus peringkat kesehatan, maka kinerja manajemen dianggap telah berhasil.

Kemudian terakit dengan tujuan untuk maksimalisasi kekayaan pemilik (shareholders), maka kinerja agen dapat dilihat dari nilai instrinsik saham selain nilai wajar saham.

\subsection{Teori Sinyal}

Teori sinyal (Spence, 1973 dalam Ghozali, 2020) menjelaskan tindakan yang diambil oleh pemberi sinyal untuk mempengaruhi perilaku penerima sinyal. Dalam kaitannya dengan praktik di bidang akuntansi dan manajemen keuangan, teori ini menjelaskan bagaimana manajemen memberikan sinyal melalui informasi kepada kepada stakeholders untuk mempengaruhi perilaku mereka. Laporan keuangan merupakan salah satu informasi yang dapat mempengaruhi perilaku stakeholders.

Kinerja perusahaan akan mempengaruhi keputusan investasi. Kinerja perusahaan yang baik akan memberikan sinyal yang baik bagi stakeholder untuk membuat keputusan. Di perbankan, salah satu sinyal tersebut dapat berupa hasil penilaian kesehatan perbankan. Peringkat kesehatan perbankan yang baik akan memberikan sinyal yang baik pula, serta akan mempengaruhi harga saham di pasar (Titman et al., 2018).

Dengan melakukan penilaian kesehatan BJBR, diharapkan hasil penilaian akan memberikan sinyal mengenai kinerja dan operasi BJBR. Pada saat tingkat kesehatan semakin bagus, maka akan memberikan informasi (sinyal) yang baik pula yang diharapkan akan mempengaruhi harga saham BJBR.

\subsection{Kesehatan Perbankan}

Atas grand theory di atas, maka perlu untuk menilai kesehatan perbankan. Tingkat kesehatan perbankan dinilai sesuai dengan Peraturan Otoritas Jasa Keuangan Nomor 04/POJK.03/2016 tentang Penilaian Tingkat Kesehatan Bank Umum.

Menurut Sri Y (2000) dikutip dalam Subhan 2019), kesehatan bank merupakan kemampuan suatu bank dalam menjalankan kegiatan operasionalnya secara normal dan memenuhi kewajibannya dengan baik melalui langkah-langkah tertentu yang sesuai dengan peraturan yang berlaku. Suatu bank dikatakan sehat apabila bank tersebut dapat menjalankan kegiatan operasi sehari-harinya secara normal dan dapat memenuhi kewajibannya dengan baik.

Berdasarkan Peraturan Otoritas Jasa Keuangan Nomor 04/POJK.03/2016 tentang Penilaian Tingkat Kesehatan Bank Umum, tingkat kesehatan bank adalah "hasil penilaian kondisi bank yang dilakukan terhadap risiko dan kinerja bank". Penilaian tingkat kesehatan bank sesuai Peraturan Otoritas Jasa Keuangan Nomor 04/POJK.03/2016 dilakukan dengan menggunakan pendekatan risiko (Risk-based Bank Rating) yang mencakup penilaian terhadap faktor RGEC sebagai berikut:

1) Profil Risiko

Penilaian terhadap faktor profil risiko (risk profile) merupakan penilaian terhadap risiko melekat bank dan kualitas pengeloaan risiko. Terdapat delapan risiko bawaan bank, namun hanya dua yang dapat diukur menggunakan rasio keuangan, yaitu risiko kredit dan risiko likuiditas Swandewi \& Purnawati (2021). Untuk mengukur profil risiko, penulis hanya mengukur dari sisi risiko kredit dan risiko likuiditas seperti penelitian Sari \& Tasman (2020), Wawan Darmawan \& Salam (2020), Kripen Kansil et al. (2020), Subhan (2019).

a. Risiko Kredit

Risiko kredit adalah risiko apabila nasabah tidak dapat memenuhi kewajibannya kepada bank. Risiko kredit dapat diukur menggunakan rasio NonPerforming Loan (NPL) yang merupakan rasio kredit bermasalah terhadap total kredit yang diberikan. Tabel 1 di bawah memperlihatkan klasifikasi kesehatan bank berdasarkan NPL.

Tabel 1. Kriteria Kesehatan Bank berdasarkan NPL

\begin{tabular}{|l|l|l|}
\hline Peringkat & Keterangan & Kriteria \\
\hline 1 & Sangat Sehat & $\mathrm{NPL}<2 \%$ \\
\hline 2 & Sehat & $2 \% \leq \mathrm{NPL}<5 \%$ \\
\hline 3 & Cukup Sehat & $5 \% \leq \mathrm{NPL}<8 \%$ \\
\hline 4 & Kurang Sehat & $8 \% \leq \mathrm{NPL}<12 \%$ \\
\hline 5 & Tidak Sehat & $\mathrm{NPL} \geq 12 \%$ \\
\hline
\end{tabular}

Sumber: Diolah dari Surat Edaran Bank Indonesia Nomor 6/23/DPNP 2004

b. Risiko Likuiditas

Risiko likuiditas adalah risiko yang terjadi apabila bank tidak mampu melunasi kewajibannya. Risiko likuiditas dapat diukur menggunakan Loan to Deposit Ratio (LDR).

Menurut Saleh \& Winarso (2021), rasio LDR akan mengindikasikan besarnya risiko likuiditas. Naiknya rasio LDR akan meningkatkan risiko 
likuiditas. Tabel 2 adalah kriteria mengenai penetapan peringkat kesehatan berdasarkan rasio LDR.

Tabel 2. Kriteria Kesehatan Bank Berdasarkan LDR

\begin{tabular}{|l|l|l|}
\hline Peringkat & Keterangan & Kriteria \\
\hline 1 & Sangat Sehat & $50 \%<$ LDR $\leq 75 \%$ \\
\hline 2 & Sehat & $75 \%<$ LDR $\leq 85 \%$ \\
\hline 3 & Cukup Sehat & $85 \%<$ LDR $\leq 100 \%$ \\
\hline 4 & Kurang Sehat & $100 \%<$ LDR $\leq 120 \%$ \\
\hline 5 & Tidak Sehat & LDR $>120 \%$ \\
\hline \multicolumn{3}{|c|}{ Sumber : Diolah dari Surat Edaran Bank Indonesia } \\
Nomor 6/23/DPNP 2004
\end{tabular}

\section{2) Good Corporate Governance (GCG)}

Penilaian terhadap faktor GCG merupakan penilaian terhadap kualitas manajemen bank yang didasarkan atas prinsip Tata Kelola yang baik. Berdasarkan Surat Edaran Otoritas Jasa Keuangan (OJK) Nomor 13/SEOJK.03/2017 tentang Penerapan Tata Kelola Bagi Bank Umum, terdapat lima prinsip dasar Tata Kelola yang baik yang harus diterapkan pada industri perbankan antara lain, transparansi, akuntabilitas, pertanggungjawaban, independensi, dan kewajaran. Selain itu, Surat Edaran OJK Nomor 13/SEOJK.03/2017 juga menyebutkan bahwa untuk memastikan penerapan lima prinsip tersebut, bank harus melakukan self-assessment terhadap faktorfaktor penilaian sebagai berikut.

a. Pelaksanaan tugas dan tanggung jawab Direksi.

b. Pelaksanaan tugas dan tanggung jawab Dewan Komisaris.

c. Kelengkapan dan pelaksanaan tugas komite.

d. Penanganan benturan kepentingan.

e. Penerapan fungsi kepatuhan.

f. Penerapan fungsi audit intern.

g. Penerapan fungsi audit ekstern.

h. Penerapan manajemen risiko termasuk sistem pengendalian intern.

i. Penyediaan dana kepada pihak terkait (related party) dan penyediaan dana besar (larger exposure).

j. Transparansi kondisi keuangan dan non keuangan Bank, laporan pelaksanaan tata kelola dan pelaporan internal.

3) Rencana strategis Bank.

Berdasarkan Surat Edaran OJK Nomor 13/SEOJK.03/2017, penerapan Tata Kelola memerlukan keberadaan Komisaris Independen untuk menghindari benturan kepentingan yang terjadi di seluruh tingkatan atau jenjang organisasi bank dalam menjalankan tugasnya, dan melindungi kepentingan stakeholders. Sementara itu, menurut Tadjudin dkk. (2016, dikutip dalam Sudarmanto dkk., 2021), penerapan Good Corporate Governance dapat memberikan peningkatan terhadap kinerja perusahaan khususnya kualitas laporan keuangan dan mengurangi tindakan manajer untuk memanipulasi laporan keuangan. Dalam penelitian ini, aspek GCG tidak akan dinilai.

4) Earnings

Penilaian mengenai faktor rentabilitas (earnings) merupakan penilaian terhadap kinerja yang diukur dari sisi profitabilitas. Kasmir (2019) menyatakan bahwa rentabilitas mengukur tingkat efisiensi dan profitabilitas suatu bank dalam menjalankan kegiatan usahanya. Rentabilitas antara lain dapat diukur menggunakan rasio-rasio keuangan sebagai berikut.

a. Return on Assets (ROA)

Berdasarkan Surat Edaran Bank Indonesia Nomor 6/23/DPNP Tahun 2004, Return On Assets (ROA) merupakan rasio laba sebelum pajak terhadap rata-rata total aset. Menurut Kasmir (2019), Return on Assets digunakan untuk mengukur kemampuan bank dalam memperoleh keuntungan dan manajerial efisiensi secara keseluruhan. ROA mengukur seberapa efisien bank dalam mengelola asetnya untuk menghasilkan keuntungan (Puspitasari dkk., 2021). Semakin tinggi ROA suatu bank maka tingkat kesehatan bank tersebut semakin tinggi. Tabel 3 menunjukkan kriteria mengenai penetapan peringkat kesehatan bank berdasarkan ROA.

Tabel 3. Kriteria Kesehatan Bank Berdasarkan ROA

\begin{tabular}{|l|l|l|}
\hline Peringkat & Keterangan & Kriteria \\
\hline 1 & Sangat Sehat & $\mathrm{ROA} \geq 2 \%$ \\
\hline 2 & Sehat & $1,25 \% \leq \mathrm{ROA}<2 \%$ \\
\hline 3 & Cukup Sehat & $0,5 \% \leq \mathrm{ROA}<1,25 \%$ \\
\hline 4 & Kurang Sehat & $-0,25 \% \leq \mathrm{ROA}<0,5 \%$ \\
\hline 5 & Tidak Sehat & $\mathrm{ROA}<-0,25 \%$ \\
\hline
\end{tabular}

Sumber: Diolah dari Surat Edaran Bank Indonesia Nomor 6/23/DPNP 2004

b. Net Interest Margin (NIM)

Sesuai dengan Surat Edaran Bank Indonesia Nomor 6/23/DPNP Tahun 2004, Net Interest Margin (NIM) merupakan rasio pendapatan bunga bersih yang diperoleh bank terhadap rata-rata aktiva produktif yang menghasilkan bunga (interestbearing assets).

Menurut Puspitasari dkk. (2021), Net Interest Margin adalah ukuran perbedaan antara pendapatan bunga yang diperoleh bank atau lembaga keuangan lain dengan beban bunga yang dibayarkan kepada pemberi pinjamannya terhadap jumlah aset mereka yang menghasilkan bunga (interest-bearing assets). Saksonova (2014, dikutip dalam Puspitasari dkk., 2021) berpendapat bahwa NIM merupakan kriteria yang paling tepat dalam menilai tingkat efektivitas dan stabilitas operasional bank. Semakin tinggi NIM suatu bank maka semakin 
sehat bank tersebut. Tabel 4 menunjukkan kriteria penetapan peringkat kesehatan bank berdasarkan NIM.

Tabel 4. Kriteria Kesehatan Bank Berdasarkan NIM

\begin{tabular}{|l|l|l|}
\hline Peringkat & Keterangan & Kriteria \\
\hline 1 & Sangat Sehat & $\mathrm{NIM} \geq 2,5 \%$ \\
\hline 2 & Sehat & $2 \% \leq \mathrm{NIM}<2,5 \%$ \\
\hline 3 & Cukup Sehat & $1,5 \% \leq \mathrm{NIM}<2 \%$ \\
\hline 4 & Kurang Sehat & $1 \% \leq \mathrm{NIM}<1,5 \%$ \\
\hline 5 & Tidak Sehat & $\mathrm{NIM}<1 \%$ \\
\hline
\end{tabular}

Sumber: Diolah dari Surat Edaran Bank Indonesia Nomor 6/23/DPNP 2004

\section{4) Kecukupan Modal}

Penilaian atas faktor permodalan (capital) merupakan penilaian terhadap kecukupan permodalan dan pengelolaan permodalan. Menurut Anggari \& Dana (2020), permodalan adalah faktor yang perlu diperhatikan oleh bank karena keberhasilan kegiatan bank sangat bergantung pada tingkat kecukupan modal yang dapat mendorong operasional bank. Tingkat kecukupan modal dapat diukur menggunakan rasio Capital Adequacy Ratio (CAR).

Menurut Puspitasari dkk. (2021), semakin tinggi CAR menunjukkan bahwa bank memilki modal yang dalam menghadapi kerugian yang tidak terduga. Tabel 5 adalah kriteria kesehatan bank berdasarkan tingkat kecukupan modal (CAR).

Tabel 5. Kriteria Kesehatan Bank Berdasarkan CAR

\begin{tabular}{|l|l|l|}
\hline Peringkat & Keterangan & Kriteria \\
\hline 1 & Sangat Sehat & CAR $\geq 10 \%$ \\
\hline 2 & Sehat & $9 \% \leq$ CAR $<10 \%$ \\
\hline 3 & Cukup Sehat & $8 \% \leq$ CAR $<9 \%$ \\
\hline 4 & Kurang Sehat & $7 \% \leq$ CAR $<8 \%$ \\
\hline 5 & Tidak Sehat & CAR $<7 \%$ \\
\hline
\end{tabular}

Sumber: Diolah dari Surat Edaran Bank Indonesia Nomor 6/23/DPNP 2004

Dari penjelasan di atas, maka variabel yang digunakan dalam penelitian ini adalah tingkat kesehatan perbankan. Tingkat kesehatan perbankan diukur menggunakan ukuran profil risiko, tata kelola perusahaan, rentabiltas perusahaan dan tingkat kecukupan modal.

\section{METODE PENELITIAN}

Penelitian ini merupakan penelitian kuantitatif deskriptif dengan objek penelitian adalah Bank Pembangunan Daerah Jawa Barat dan Banten (BJBR) dengan periode penelitian adalah tahun 2018-2020. Menurut Sugiyono (2009), penelitian deskriptif kuantitatif menggambarkan data kuantitatif yang diperoleh menyangkut keadaan subjek atau fenomena. Dalam hal ini, data kuantitatif diperoleh dari perhitungan rasio keuangan untuk menggambarkan tingkat kesehatan Bank BJBR.

Penelitian ini menggunakan data laporan keuangan BJBR tahun 2018 sampai dengan tahun 2020. Laporan keuangan diambil dari laman Bursa Efek Indonesia (idx.co.id).

Sesuai dengan Sugiyono (2009), dalam penelitian deskriptif diperlukan adanya kriteria. Oleh karena itu, kriteria yang digunakan dalam penelitian ini adalah regulasi atau peraturan yang ditetapkan oleh otoritas yang berwenang, dalam hal ini Bank Indonesia (BI) dan Otoriras Jasa Keuangan (OJK).

Dalam melakukan analisis, penulis menggunakan regulasi yang ditetapkan oleh Otoritas Jasa Keuangan yaitu Peraturan OJK Nomor 04/POJK.03/2016 tentang Penilaian Tingkat Kesehatan Bank Umum yaitu dengan pendekatan risiko (Risk-based Bank Rating) yang mencakup penilaian terhadap faktor RGEC (Risk Profile, Good Corporate Governance, Earning, and Capital). Selain itu, penulis juga menggunakan regulasi yang ditetapkan oleh Bank Indonesia seperti Surat Edaran Bank Indonesia Nomor 6/23/DPNP Tahun 2004 dan Surat Edaran Bank Indonesia Nomor 13/24/DPNP/2011 tentang Penilaian Tingkat Kesehatan Bank Umum, serta Peraturan Bank Indonesia Nomor 13/1/PBI/2011 tentang Penilaian Tingkat Kesehatan Bank Umum yang menetapkan system penilaian kesehatan bank umum menggunakan pendekatan Risk Based Bank Rating (RBRR) yang disebut juga dengan RGEC.

Variabel yang digunakan dalam penelitian ini adalah tingkat kesehatan perbankan yang diukur dengan profil risiko (NPL dan LDR), tingkat rentabilitas (ROA dan NIM), dan tingkat kecukupan modal (CAR). Untuk tata kelola tidak dinilai karea bersifat penilaian mandiri oleh bank bersangkutan.

Untuk menentukan peringkat kesehatan bank, maka hasil perhitungan rasio keuangan akan dibandingkan dengan kriteria yang ditetapkan oleh regulasi yang ada. Dalam rangka menyimpulkan kondisi kesehatan secara umum akan dihitung nilai peringkat komposit (PK). PK dihitung dengan formula:

$$
P K=\frac{\text { Jumlah Bobot Nilai Semua Rasio }}{\text { Total Nilai Maksimal Komposit Semua Rasio }}
$$

Jumlah komposit rasio diukur dengan menjumlahkan bobot nilai setiap peringkat. Peringkat 1 akan diberikan bobot 5, peringkat 2 diberikan bobot 4 dan seterusnya sampai dengan peringkat 5 diberikan bobot 1 . Setelah didapatkan 
nilai PK, maka hasilnya akan dibandingkan dengan kriteria pada Surat Edara Bank Indonesia Nomor 13.24/DPNP/2011 dengan aturan:

a. PK bernilai $86-100 \%$ memiliki peringkat sangat sehat

b. PK bernilai $71-85 \%$ memiliki peringkat sehat

c. PK bernilai $61-70 \%$ memiliki peringkat cukup sehat

d. PK bernilai 41-60\% memiliki peringkat kurang sehat

e. PK bernilai di bawah $40 \%$ memiliki peringkat tidak sehat

Hasil peringkat kesehatan kemudian akan dibandingkan antara periode sebelum pandemic dan selama pandemic covid-19 (PK2018, PK 2019 dibandingkan dengan PK 2020). Periode sebelum pandemic covid menggunakan laporan keuangan tahun 2018 dan 2019, sedangkan periode selama pandemic covid-19 menggunakan laporan keuangan tahun 2020. Penulis hanya membatasi penilaian kesehatan pada aspek profil risiko, earning dan capital.

Untuk menentukan nilai intrinsic saham $\mathrm{BJBR}$, penulis menggunakan metode dividend discount model (DDM) dengan pendekatan pertumbuhan konstan (constan growth model) sesuai Titman et al. (2018).

\section{HASIL PENELITIAN}

\subsection{Analisis RGEC}

Perhitungan non-performing loan BJBR dapat dilihat pada tabel 6. Dari tabel tersebut, dapat diketahui bahwa risiko kredit BJBR dari tahun 2018-2020 semakin rendah yang diukur dengan menurunnya NPL. Semakin rendah NPL, semakin rendah risiko kreditnya (Kumar, Basuki, \& Rahmat, 2021).

Tabel 6. Hasil Perhitungan NPL Tahun 2018-2020

\begin{tabular}{|l|r|l|l|c|}
\hline Tahun & $\begin{array}{l}\text { Kredit } \\
\text { Bermasalah }\end{array}$ & $\begin{array}{l}\text { Total } \\
\text { Kredit }\end{array}$ & NPL & Peringkat \\
\hline 2018 & 1.268 .332 & 75.349 .849 & $1,68 \%$ & 1 \\
\hline 2019 & 1.331 .971 & 81.887 .246 & $1,63 \%$ & 1 \\
\hline 2020 & 1.289 .764 & 89.450 .934 & $1,44 \%$ & 1 \\
\hline
\end{tabular}

Berdasarkan tabel di atas, dapat dilihat bahwa risiko kredit BJBR semakin kecil. Artinya kemungkinan terjadinya kredit macet semakin berkurang. Dengan nilai NPL di bawah 20\%, peringkat NPL BJBR tahun 2018-2020 dikategorikan sangat sehat.

Hasil penilaian ini sama dengan penelitian Putri (2021) yang menghasilkan penilaian kesehatan BJBR tahun 2018 dan 2019 dari sisi NPL nya dalam peringkat sangat sehat. Kondisi ini dapat terjadi karena selama kondisi pandemi, perbankan mengerem kredit kepada pihak ketiga untuk menghindari terjadinya kredit macet.

Analisis profil risiko yang berikutnya dilihat dari sisi risiko likuiditas yang diukur dengan rasio LDR. Hasil perhitungan rasio LDR BJBR dapat dilihat pada tabel 7 .

Tabel 7. Hasil Perhitungan LDR Tahun 2018-2020

\begin{tabular}{|l|l|l|c|c|}
\hline Tahun & $\begin{array}{l}\text { Total } \\
\text { Kredit }\end{array}$ & $\begin{array}{l}\text { Dana } \\
\text { Pihak } \\
\text { Ketiga }\end{array}$ & LDR & Peringkat \\
\hline 2018 & 75.349 .849 & 81.609 .421 & $92 \%$ & 3 \\
\hline 2019 & 81.887 .246 & 83.339 .717 & $98 \%$ & 3 \\
\hline 2020 & 89.450 .934 & 99.559 .020 & $89,8 \%$ & 3 \\
\hline
\end{tabular}

Pada tabel 7 dapat diketahui bahwa LDR BJBR selama 2018-2020 berfluktuasi, namun masih diantara $85 \%$ dan $100 \%$. Peringkat kesehatan BJBR dari sisi likuiditas selama 2018-2020 ada di peringkat ketiga yang artinya cukup sehat. LDR yang rendah menunjukkan bahwa BJBR memiliki likuiditas yang baik karena tidak banyak dana pihak ketiga yang disalurkan menjadi kredit kepada masyarakat.

Dari dua rasio di atas, penilaian kesehatan dari aspek rasio dapat dilakukan dengan menghitung peringkat kompositnya. Hasilnya adalah PK dari aspek risiko bernilai $80 \%$ yang mengindikasikan aspek risiko BKBR dalam kondisi sehat. Hasil analisis ini sama dengan hasil penelitian dari Putri (2021) dan Rohendi (2017).

Analisis berikutnya adalah analisis earning yang diukur dengan ROA dan NIM. Hasil perhitungan ROA BJBR ditunjukkan dalam Tabel 8.

Tabel 8. Hasil Perhitungan ROA Tahun 2018-2020

\begin{tabular}{|l|l|l|l|c|}
\hline Tahun & Laba & $\begin{array}{l}\text { Average } \\
\text { Total Asset }\end{array}$ & ROA & Peringkat \\
\hline 2018 & 1.937 .044 & 112.496 .671 & $1,72 \%$ & 2 \\
\hline 2019 & 1.977 .962 & 118.016 .573 & $1,68 \%$ & 2 \\
\hline 2020 & 2.168 .028 & 129.475 .288 & $1,67 \%$ & 2 \\
\hline
\end{tabular}

Berdasarkan tabel 8 di atas, terlihat bahwa ROA BJBR mengalami penurunan. Hal tersebut sebenarnya sesuai dengan kinerja perbankan di tahun 2020 yang mengalami penurunan yang dipublikasikan pada laporan profil industri perbankan 2020 (Otoritas Jasa Keuangan, 2020a). Kinerja perbankan pada saat pandemic menurun apabila dibadingkan dengan tahun sebelumnya. Walaupun laba BJBR naik, namun kenaikan tidak sebanding dengan kenaikan asetnya.

Dari hasil penilaian, diperoleh bahwa ROA BJBR berada pada peringkat 2 yang berarti sehat. Walaupun terjadi penurunan trend ROA, namun 
peringkat kesehatan ROA tidak berubah. Hasil ini sama dengan hasil yang diperoleh oleh Putri (2021). Sehingga dapat disimpulkan bahwa secara peringkat kesehatan, nilai ROA BJBR dari tahun 2017-2020 adalah sehat (peringkat 2). Peringkat 2 disini mengindikasikan bahwa perusahaan masih baik dalam menghasilkan pendapatan dan laba.

Ukuran rentabilitas selanjutnya adalah adalan NIM. Pada tabel 9 terlihat bahwa rasio NIM BJBR mengalami penurunan dari tahun-tahun sebelumnya. Namun, kinerja di paruh kedua 2020 BJBR naik drastik apabila dibandingkan denga semester 1. Hal ini dikarenakan di semester kedua, pembatasan kegiatan ekonomi sudah dilonggarkan (Putra, 2021).

Kinerja keuangan BJBR di 2021 juga terus melaju apabila dilihat dari profitabilitasnya. Berdasarkan laporan keuangan semester 1 tahun 2021, laba bersih BJBR naik lebih dari 14\% (Alfi, 2021).

Tabel 9. Hasil Perhitungan NIM Tahun 2018-2020

\begin{tabular}{|l|c|l|r|c|}
\hline Tahun & $\begin{array}{l}\text { Pendapatan } \\
\text { Bunga }\end{array}$ & $\begin{array}{l}\text { Average } \\
\text { Aset }\end{array}$ & NIM & Peringkat \\
\hline 2018 & 6.499 .031 & 97.283 .928 & $6,7 \%$ & 1 \\
\hline 2019 & 6.082 .506 & 100.341 .528 & $6,06 \%$ & 1 \\
\hline 2020 & 6.497 .264 & 110.472 .153 & $5,88 \%$ & 1 \\
\hline
\end{tabular}

Berdasarkan tabel 9, terlihat bahwa NIM BJBR masih berada pada peringkat 1 ( $\mathrm{NIM}>5 \%)$ yang berarti sangat sehat. BJBR masih sangat baik dalam mendapatkan tingkat hasil bunga bersih dari pemberian kredit ke pihak ketiga dan investasi lainnya.

Untuk menilai aspek earning, maka perlu dihitung nilai peringkat kompositnya yaitu dengan menjumlahkan bobot peringkat pada ROA dan NIM kemudian dibagi dengan total maksimal nilai bobot (10). Hasil nilai kompositnya adalah $90 \%$ $((4+5) / 10))$ yang artinya dari sisi aspek earning (kemampuan menghasilkan laba), BJBR berada pada peringkat 1 atau sangat sehat. BJBR masih mampu menghasilkan laba perusahaan dengan sangat baik. Hasil peringkat kesehatan ini berbeda dengan Rohendi (2017) yang menyimpulkan kesehatan BJBR dari aspek earning berada pada peringkat 2 atau sehat. Perbedaan ini disebabkan tahun analisis, yaitu Rohendi (2017) menanalisis laporan keuangan tahun 2013-2015.

Hasil berbeda juga diperlihatkan oleh (Putri, 2021) yang menghasilkan aspek earning BJBR di tahun 2018 ada di peringkat 2 dan di tahun 2019 ada di peringkat 1 . Perbedaan ini dikarenakan adanya rasio keuangan yang digunakan. Putri (2021) menggunakan rasio ROA dan BOPO dalam menilai aspek earning, sedangkan penelitian ini menggunakan ROA dan NIM. Penggunaan NIM disini dikarenakan menurut Saksonova (2014, dikutip dalam Puspitasari dkk., 2021) NIM merupakan kriteria yang paling tepat dalam menilai tingkat efektivitas dan stabilitas operasional bank.

Setelah melihat aspek earning, analisis selanjutnya terkait dengan kecukupan modal. Hasil perhitungan CAR dapat dilihat pada tabel 10.

Tabel 10. Hasil Perhitungan CAR Tahun 2018-2020

\begin{tabular}{|l|l|l|l|c|}
\hline Tahun & Modal & ATMR & CAR & Peringkat \\
\hline 2018 & 11.039 .180 & 59.243 .425 & $18,63 \%$ & 1 \\
\hline 2019 & 11.391 .189 & 64.308 .062 & $17,71 \%$ & 1 \\
\hline 2020 & 12.796 .321 & 73.923 .122 & $17,31 \%$ & 1 \\
\hline
\end{tabular}

Berdasarkan tabel 10, dapat dilihat bahwa CAR BJBR mengalami penurunan. Semakin besar nilai CAR, maka semakin sehat perusahaan apabila dilihat dari kecukupan modal. Berdasarkan kodifikasi penilaian kesahatan bank, maka CAR BJBR masuk ke dalam peringkat 1 yang artinya Sangat Sehat.

Hasil penilaian di atas sama dengan penelitian Putri (2021). Penelitian Putri (2021) di tahun 2018 dan 2019 menghasilkan CAR pada peringkat 1 . Dengan CAR yang sangat sehat mengindikasikan bahwa BJBR memilki modal yang sangat besar untuk melakukan kegiatan operasi, investasi dan pembiyaan dengan sangat baik.

Untuk menilai tingkat kesehatan secara menyeluruh, maka dilakukan pembobotan nilai atas peringkat setiap rasio keuangan yang digunakan untuk menghitung peringkat komposit (PK). Hasil penghitungan PK dapat dilihat pada tabel 11.

Dengan mengesampingkan penilaian aspek good corporate governance, maka kondisi kesehatan BJBR secara keseluruhan dari tahun 2018-2020 digolongkan ke dalam Sangat Sehat, yaitu dengan PK 88\%. Penghitungan PK tersebut seirama dengan nilai rata-rata peringkat dari aspek risiko (Sehat), earning (Sangat Sehat), dan kecukupan modal (Sangat Sehat). Hasil ini berbeda dengan hasil penelitian Putri (2021) dan Rohendi (2017) yang hasilnya adalah sehat. Seperti dijelaskan di atas, perbedaan tersebut kemungkinan disebabkan oleh adanya perbedaan metode analisisi, perbedaan waktu analisis, dan perbedaan rasio keuangan yang digunakan.

Tabel 11. Hasil Penilaian Kesehatan BJBR 


\begin{tabular}{|r|r|r|r|r|r|r|r|}
\hline Peringkat & \multicolumn{1}{|c|}{ NPL } & \multicolumn{1}{c|}{ LDR } & \multicolumn{1}{c|}{ ROA } & NIM & CAR & PK & \% PK \\
\hline 2018 & 1 & 3 & 2 & 1 & 1 & & \\
\hline Bobot Nilai & 5 & 3 & 4 & 5 & 5 & 22 & 0,88 \\
\hline 2019 & 1 & 3 & 2 & 1 & 1 & & \\
\hline Bobot Nilai & 5 & 3 & 4 & 5 & 5 & 22 & 0,88 \\
\hline 2020 & 1 & 3 & 2 & 1 & 1 & & \\
\hline Bobot Nilai & 5 & 3 & 4 & 5 & 5 & 22 & 0,88 \\
\hline
\end{tabular}

\subsection{Analisis Kinerja Sebelum dan Selama}

\section{Pandemi Covid-19}

Apabila melihat sisi kinerja sebelum dan selama pandemic Covid-19, terliha bahwa terdapat trend menurun dari sisi rasio keuangan. Untuk nilai NPL cenderung turun di masa pandemic. Hal ini mengindikasikan bahwa selama masa pandemic cenderung semakin sehat. Salah satunya dikarenakan adanya kelonggaran aturan dan perubahan bisnis model bank yang resilient dan kemampuan adaptasi perusahaan yang agile (Tempo.co, 2021). Apabila dinilai menggunakan POJK Nomor 04/POJK.03/2016, maka kondisi kesehatan BJBR terkait dengan aspek risiko kredit sebelum dan selama Pandemi Covid-19 tidak ada perbedaan, yaitu dalam kondisi sangat sehat.

Selanjutnya, dari sisi LDR juga terlihat terjadi penurunan dari tahun 2019 ke tahun 2020. Kondisi pandemic membuat perbankan mengerem penyaluran kredit kepada nasabah. Hal ini yang menyebabkan dana untuk pihak ketiga menjadi longgar (Hastuti, 2021). Berbeda dengan aspek risiko kredit, untuk risiko likuiiditas, kondisi kesehatan BJBR baik sebelum dan selama pandemic covid-19 berada pada kondisi cukup sehat.

Tingkat profitabilitas yang diukur dengan ROA dan NIM juga mengalami penurunan dari sebelum dan selama masa pandemic. Hal ini dikarenakan adanya pelambatan penyaluran kredit dan penurunan suku bunga (Sitanggang, 2020). Apabila diukur menggunakan POJK Nomor 04/POJK.03/2016, aspek rentabilitas BJBR apabila dinilai menggunakan rasio ROA, baik sebelum dan selama pandemic covid-19 berada pada peringkat sehat. Sedangkan, apabila diukur menggunakan rasio NIM, baik sebelum dan selama pandemic covid-19 berada pada peringkat sangat sehat.

Seirama dengan rasio keuangan lainnya, rasio kecukupan modal BJBR juga mengalami penurunan dari tahun 2018. Hal ini juga membuktikan bahwa pandemic covid-19 memberikan efek menurunnya rasio kecukupan modal. Namun, apabila dinilai menggunakan standard yang ada, maka kondisi sebelum dan selama pandemic, rasio CAR BJBR dalam kondisi sangat sehat.

Secara keseluruhan, perbedaan kesehatan BJBR sebelum dan selama pandemic covid-19 hanya ada pada penurunan nilai rasio-nya.
Sedangkan peringkat kesehatan berdasarkan regulasi yang ada tidak mengalami perubahan.

\subsection{Valuasi Saham BJBR}

Setelah melihat kinerja dan kondisi kesehatan BJBR berdasarkan pendekatan RGEC, penulis berikutnya akan membahas valuasi saham BJBR. Dalam melakukan valuasi, penulis akan menggunakan metode dividend growth model atau metode discounted dividend model.

Untuk menghitung nilai fundamental saham BJBR, langkah pertama adalah menentukan nilai pertumbuhannya atau growth (g). Kemudian, setelah mendapatkan nilai g, dilakukan peramalan nilai dividen tahun berikutnya. Langkah berikutnya adalah menghitung nilai biaya modal atas ekuitas (KCs). Setelah itu, nilai intrinsic saham BJBR dihitung dengan menggunakan formula:

$$
V c s=\frac{D 2021}{K c s-g}
$$

Proyeksi pertumbuhan atau growth (g) dihitung dengan menggunakan rata-rata pertumbuhan dividen tahun 2018-2020. Berdasarkan tabel 12, terlihat bahwa nilai g yang dihasilkan sebesar $3 \%$.

Tabel 12. Nilai Pertumbuhan Dividen

\begin{tabular}{|r|c|r|r|r}
\hline \multicolumn{1}{|c|}{ Tahun } & Dividen & $\begin{array}{c}\text { Jumlah Lembar } \\
\text { Saham }\end{array}$ & $\begin{array}{c}\text { Dividen per } \\
\text { lembar }\end{array}$ & Growth \\
\hline 2018 & 879.586 .000 .000 & 9.838 .787 .161 & 89,400 & \\
\hline 2019 & 925.044 .000 .000 & 9.838 .787 .161 & 94,020 & $5 \%$ \\
\hline 2020 & 941.960 .000 .000 & 9.838 .787 .161 & 95,739 & $2 \%$ \\
\hline \multicolumn{3}{|c|}{ Rata-Rata Growth } & & $3 \%$ \\
\hline
\end{tabular}

Setelah menghitung nilai g, maka nilai estimasi dividen tahun 2021 dapat dihitung dengan:

$$
\begin{aligned}
& \text { Dividen2021 }=\text { Dividen } 2020 \times(1+g) \\
& \text { Dividen2021 }=R p 95,739 \times(1+3 \%) \\
& \text { Dividen2021 }=R p 99,088
\end{aligned}
$$

Langkah selanjutnya adalah menghitung cost of equity ( $\mathrm{CoE}$ ). Pendekatan yang digunakan dalan menghitung cost of equity dalam penelitian ini adalah dengan menggunakan rumus capital asset pricing model (CAPM). Untuk menghitung CoE, maka perlu mencari nilai beta, free risk rate of return (Rf), dan market return (Rm). Beta diambil dari data pefindo (https://www.pefindo.com/fileman/file/722).

Data Risk free asset diambil dari Indonesian Bond Pricing Agency (http://www.ibpa.co.id). Market return diambil dari market risk premia.com (http://www.market-risk-premia.com/id.html). 
Hasil dari perhitungan menunjukkan bahwa cost of equity BJBR adalah 9,47\% seperti yang ada di tabel 13.

Tabel 13. Perhitungan Cost of Equity

\begin{tabular}{|c|c|c|c|}
\hline cost of equity & Per 31-Des-2018 & Per 31-Des-2019 & Per 31-Des-2020 \\
\hline raw beta BJBR per & 1,043 & 0,987 & 1,201 \\
\hline adjusment beta of bjbr & 1,029 & 0,991 & 1,134 \\
\hline risk free & $7,98 \%$ & $7,10 \%$ & $6,10 \%$ \\
\hline market risk premium & $2,01 \%$ & $2,39 \%$ & $2,46 \%$ \\
\hline market rate return & $9,99 \%$ & $9,49 \%$ & $8,56 \%$ \\
\hline cost of equity & $10,05 \%$ & $9,47 \%$ & $8,89 \%$ \\
\hline average cost of equity & \multicolumn{3}{|c}{} \\
\hline
\end{tabular}

Setelah mendapatkan nilai CoE, langkah terakhir adalah menghitung nilai intrinsik saham BJBR. Nilai saham BJBR dihitung dengan:

$$
\begin{aligned}
V C S & =\frac{R p 99.088}{9,47 \%-3 \%} \\
V C S & =R p 1.659,33
\end{aligned}
$$

Hasil perhitungan menunjukkan bahwa nilai intrinsik saham BJBR per 31 Desember 2020 adalah Rp1.659,33. Apabila dibandingkan dengan harga saham BJBR pada akhir tahun 2020 yaitu Rp1.457,54, nilai saham BJBR dinilai lebih rendah (underpriced). Apabila dibandingkan dengan harga saham pada tanggal 27 Agustus 2021, nilai saham BJBR juga masih dinilai lebih rendah.

Hasil perhitungan tersebut berbeda dengan perhitungan Hartono (2020) dan Afandy (2019). Perbedaan dengan Hartono (2020) disebabkan adanya perbedaan metode dan tahun penelitian, sedangkan dengan Afandy (2019) disebabkan oleh tahun penelitian. Tahun penelitian tersebut akan mempengaruhi nilai beta, $\mathrm{Rf}, \mathrm{Rm}$ dan nilai dividen sebelumnya, serta tingkat pertumbuhannya (g).

Kondisi pandemic covid-19 akan mempengaruhi beta, Rf, dan $\mathrm{rm}$ apabila dibandingkan dengan masa sebelum pandemic. Pembayaran dividen juga akan terpengaruh dengan adanya pandemic yang akan menyebabkan menurunnya tingkat pertumbuhan yang digunakan.

\section{KESIMPULAN DAN SARAN}

Berdasarkan hasil pembahasan di atas, dapat disimpulkan bahwa tingkat kesehatan BJBR dengan mendasarkan pada aturan OJK dan Bank Indonesia adalah dalam kondisi sangat sehat yang diukur dari aspek risiko adalah sangat sehat (risiko kredit sangat sehat, risiko likuiditas cukup sehat), aspek earning adalah sangat sehat (ROA sehat dan NIM sangat sehat) dan aspek kecukupan modal adalah sangat sehat. Hal ini juga terkonfirmasi dari nilai peringkat komposit yang berada pada angka $88 \%$ yang digolongkan dalam kondisi sangat sehat. Kemudian, efek pandemic covid-19 tidak memberikan perbedaan pada tingkat kesehatan BJBR dari aspek risiko, aspek earning, dan aspek capital. Perbedaan kesehatan BJBR sebelum dan selama pandemic covid-19 hanya terlihat dari nilai rasionya saja. Simpulan terakhir terkait dengan nilai saham fundamental atau nilai intrinsic saham BJBR adalah dengan menggunakan metode DDM dihasilkan nilai intrinsic saham BJBR pada akhir tahun 2020 adalah Rp1.659.33. Hal ini menandakan bahwa nilai saham BJBR dinilai lebih rendah (underpriced).

Penulis memberikan saran kepada BJBR untuk dapat meningkatkan pemberian kredit dengan tetap menjaga rasio keuangan dalam kondisi sehat agar dapat menigkatkan profitabilitasnya. Efisiensi juga perlu ditingkatkan dengan harapan nilai rentabilitas juga dapat meningkat.

\section{IMPLIKASI DAN KETERBATASAN}

Hasil penelitian ini tidak ditujukan untuk memberikan rekomendasi investasi saham, namun hanya memberikan tambahan informasi apabila akan melakukan keputusan investasi. Hal ini dikarenakan informasi yang digunakan dalam peneltian ini adalah akhir tahun 2020 yang kemungkinan besar terjadi perubahan-perubahan indikator penilaian selama tahun 2021.

Penelitian ini hanya ingin melihat kondisi kesehatan BJBR sebelum dan selama masa pandemic covid-19 agar pihak yang terkait dapat memberikan perhatian atas kinerja Lembaga perbankan. Dengan informasi yang ada, diharapkan pihak OJK dan Pemerintah dapat memberikan dukungan kepada industri perbankan agar kesehatan perbankan tetap terjaga. Monitoring dan pengawasan perbankan perlu untuk ditingkatkan.

Penulis mengakui masih banyak keterbatasan atas penelitian ini, sehingga untuk penelitian selanjutnya, penulis merekomendasikan agar dapat memperpanjang periode penelitian, menggunakan obyek penelitian untuk semua bank, menggunakan pendekatan valuasi yang beragam, dan melakukan analisis bisnis, analisis industri, dan analisis akuntansi disamping analisis keuangan sebelum melakukan valuasi.

\section{DAFTAR PUSTAKA (REFERENCES)}

Afandy, C. (2019). Stock Valuation Menggunakan Dividend Discounted Model (DDM) Dalam Pengambilan Keputusan Investasi Pada Bank Pembangunan Daerah Yang Terdaftar Di Bursa Efek Indonesia, 1(1), 57-73.

https://doi.org/https://doi.org/10.33369/ mr.1.1.\%25p

Alfi, A. N. (2021). Laba Bank BJB (BJBR) Naik 14,42 Persen pada Paruh Pertama 2021. Retrieved August 23, 2021, from https://finansial.bisnis.com/read/202107 27/90/1422239/semester-i2021-laba- 
bank-bjb-bjbr-naik-1442-persen

Anggari, N. L. S., \& Dana, I. M. (2020). The Effect of Capital Adequacy Ratio, Third Party Funds, Loan to Deposit Ratio, Bank Size on Profitability in Banking Companies on IDX. American Journal of Humanities and Social Sciences Research (AJHSSR), 4(12), 334338.

Bank Indonesia. (2004). Surat Edaran Bank Indonesia Nomor 6/23/DPNP Tahun 2004.

Bank Indonesia. (2012). Kodifikasi Peraturan Bank Indonesia Kelembagaan Penilaian Tingkat Kesehatan Bank. Jakarta: Pusat Riset dan Edukasi Bank Sentral (PRES).

Bursa Efek Indonesia. (2020). Laporan Keuangan dan Tahunan.

Ciptaning, A. (2020). Kinerja 3 Emiten BPD 2020: Bank BJB Paling Gemilang, Bank Banten dan Bank Jatim Tumbang - TrenAsia. Retrieved August 23, 2021, from https://www.trenasia.com/kinerja-3emiten-bpd-2020-bank-bjb-palinggemilang-bank-banten-dan-bank-jatimtumbang

Darmawan, W., \& Salam, M. D. (2020). Analisis Tingkat Kesehatan Bank Menggunakan Metode RGEC Pada PT Bank Tabungan Negara (Persero) Tbk. Periode 2017-2019. Accounting, Accountability and Organization System (AAOS) Journal, 2(1), 51-76.

https://doi.org/10.47354/aaos.v2i1.240

Dinarjito, A. (2018). Menilai Kesehatan Bumn Konstruksi yang Terdaftar di Bursa Efek Indonesia sebagai Akibat Meningkatnya Proyek Infrastruktur Pemerintah. Substansi, 2(1), 1-18.

Faqir, A. Al. (2021). Kinerja Sektor Perbankan selama 2020 Terkontraksi Akibat Pandemi Covid-19. Retrieved from https://www.liputan6.com/bisnis/read/4 458547/kinerja-sektor-perbankan-selama2020-terkontraksi-akibat-pandemi-covid19

Ghozali, I. (2020). 25 grand theory: Teori besar ilmu manajemen, akutansi dan bisnis (Untuk landasan teori skripsi, tesis dan disertasi). Semarang: Yoga Pratama.

Hartono, W. (2020). Evaluasi Kinerja Laporan Keuangan saham BJTM dan BJBR. Jurnal Akuntansi Kontemporer (JAKO), 12(1), 4453.

https://doi.org/10.33508/jako.v12i1.2169

Hastuti, R. K. (2021). Lampaui Industri, Laba bank bjb 2020 Naik 8\% Jadi Rp 1,68 T. Retrieved August 23, 2021, from https://www.cnbcindonesia.com/market/ 20210315151552-17-230240/lampauiindustri-laba-bank-bjb-2020-naik-8-jadirp-168-t

Istihana, D., \& Mulyati, Y. (2020). Analisis Kinerja Keuangan Perusahaan Dengan Menggunakan Analisis Rasio Keuangan PAda Bank JABAR BANTEN (BJB). Jurnal Akuntansi Bisnis Dan Ekonomi, 6(2), 1695$1704 . \quad$ Retrieved from http://journal.widyatama.ac.id/index.php /jabe/article/view/619/472

Jensen, M. C., \& Meckling, W. H. (1976). Theory of the firm: Managerial behavior, agency cost and ownership structure. Journal of Financial Economics.

Kansil, K., Pelleng, F. A. O., \& Rogahang, J. J. (2020). Analisis Kinerja Keuangan untuk Menilai Kesehatan Bank Rakyat Indonesia dengan Metode Rgec. Productivity, 1(3), 291-296.

Kasmir. (2019). Analisis Laporan Keuangan Edisi Revisi (Revisi 201). Depok: PT RajaGrafindo Persada.

Kevin, A. (2019). Harga Saham Anjlok 23\%, Seperti Apa Kinerja BJB Sejak 2019? Retrieved August 23, 2021, from https://www.cnbcindonesia.com/market/ 20190809082909-17-90837

Kumar, S. S., Basuki, B., \& Rahmat, S. (2021). The Effect of Non-Performing Loan on Profitability: Empirical Evidence from Nepalese Commercial Banks. The Journal of Asian Finance, Economics and Business, 8(4), 709-716. https://doi.org/10.13106/JAFEB.2021.VOL 8.N04.0709

Otoritas Jasa Keuangan. (2016). Peraturan Otoritas Jasa Keuangan Nomor 04/POJK.03/2016 tentang Penilaian Tingkat Kesehatan Bank Umum.

Otoritas Jasa Keuangan. (2017). Surat Edaran Otoritas Jasa Keuangan Nomor 13/SEOJK.03/2017 tentang Penerapan Tata Kelola Bagi Bank Umum.

Otoritas Jasa Keuangan. (2020a). Laporan Profil Industri Perbankan: Triwulan IV 2020. Jakarta.

Otoritas Jasa Keuangan. (2020b). Laporan Profil Industri Perbankan Triwulan II-2020. Otoritas Jasa Keuangan.

Panda, B., \& Leepsa, N. M. (2017). Panda \& Leepsa, 2017. Indian Journal of Corporate Governance, 74-95.

Puspitasari, E., Sudiyatno, B., Hartono, W. E., \& Widati, L. W. (2021). Net Interest Margin and Return on Assets: A Case Study in Indonesia. The Journal of Asian Finance, Economics and Business, 8(4), 727-734. 
https://doi.org/https://doi.org/10.13106/ jafeb.2021.vol8.no4.0727

Putra. (2021). Impresif! Begini Kinerja BJBR Pada 2020. Retrieved August 23, 2021, from https://www.cnbcindonesia.com/market/ 20210208091558-17-221737/impresifbegini-kinerja-bjbr-pada-2020

Putri, B. A. (2021). Analisis RGEC Untuk Menilai Tingkat Kesehatan Bank Pada Perusahaan Perbankan Yang Terdaftar di Bursa Efek Indonesia Tahun 2017-2019. Universitas Sumatera Utara. Retrieved from http://repositori.usu.ac.id/bitstream/han dle/123456789/31670/170503005.pdf?se quence $=1$ \&isAllowed $=y$

Rohendi, H. (2017). ANALISIS KINERJA KEUANGAN DENGAN MENGGUNAKAN METODE CAMEL PADA PT BANK JABAR BANTEN. JRAK (Jurnal Riset Akuntansi Dan Bisnis), 3(2 SE-Articles). Retrieved from https://jurnal.plb.ac.id/index.php/JRAK/ar ticle/view/343

Saleh, D. S., \& Winarso, E. (2021). Analysis of NonPerforming Loans (NPL) and Loan to Deposit Ratio (LDR) towards Profitability. International Journal Multicultural and Multireligious Understanding, 8(1), 423436.

https://doi.org/http://dx.doi.org/10.1841 5/ijmmu.v8i1.2387

Sari, P. D., \& Tasman, A. (2020). Analisis Tingkat Kesehatan Perbankan dengan Pendekatan Risk Based Bank Rating (RBBR) Pada Perbankan yang Terdaftar di Bursa Efek Indonesia Tahun 2014-2018. Ecogen, 3(3), 375-384.

https://doi.org/https://doi.org/10.24036/ jmpe.v3i3.9914

Sitanggang, L. M. S. (2020). NIM Perbankan Melorot Saat Pandemi Corona, Ternyata Ini Pemicunya. Retrieved August 23, 2021, from

https://keuangan.kontan.co.id/news/nimperbankan-melorot-saat-pandemicorona-ternyata-ini-pemicunya

Sri Y, S. (2000). Bank Dan Lembaga Keuangan Lain. Jakarta: Salemba Empat.

Subhan, S. (2019). Penilaian Kinerja Keuangan Bank Dengan Pendekatan Risk-Based Bank Ratingmethod. Profita : Komunikasi Ilmiah Akuntansi Dan Perpajakan, 12(2), 208225.

https://doi.org/10.22441/profita.2019.v1 2.02.003

Sudarmanto, E., Susanti, E., Revida, E., Pelu, Mu. F. A., Purba, S., Purba, A. B., ... Krisnawati, A. (2021). Good Corporate Governance
(GCG). Yayasan Kita Menulis.

Sugiyono. (2009). Metode Penelitian Kuantitatif, Kualitatif, dan R\&D. Bandung: CV Alfabeta.

Swandewi, N. K. M., \& Purnawati, N. K. (2021). Capital Adequacy Ratio Mediates the Effect of Non-Performing Loan on Returns on Assets in Public Commercial Banks. American Journal of Humanities and Social Sciences Research (AJHSSR), 5(1), 651-656.

Tempo.co. (2021). Catatkan Laba Bersih 2020 Rp 1,7 Triliun, Bank BJB Konsisten Bertumbuh Positif. Retrieved August 23, 2021, from https://bisnis.tempo.co/read/1442658/ca tatkan-laba-bersih-2020-rp-17-triliunbank-bjb-konsisten-bertumbuh-positif

Titman, S., Keown, A. J., \& Martin, J. D. (2018). Financial Management: Principles and Applications (13th ed.). Harlow: Pearson. 